\title{
Synthesis and Molecular modeling of some new chalcones derived from coumarine as CDC25 phosphatases inhibitors
}

\author{
Delel Dridi ${ }^{1,2}$, Ahmed B. Abdelwahab ${ }^{1}$, Emilie Bana ${ }^{1}$, Patrick Chaimbault ${ }^{1}$, Faouzi Meganem ${ }^{2}$ and \\ Gilbert Kirsch ${ }^{1, *}$ \\ ${ }^{1}$ Université de Lorraine, Laboratoire de Synthèse et Réactivité des Systèmes Moléculaires Complexes UMR- \\ SRSMC 7565,Equipe Hécrin, 1 boulevard Arago, 57070 Metz Technopôle-France \\ ${ }^{2}$ Laboratoire de Synthèse Organique, Faculté des Sciences de Bizerte, Jarzouna 7021-Bizerte-Tunisie
}

\begin{abstract}
New chalcones derived from coumarines were synthesized and tested as CDC25 phosphatase inhibitors. Molecular modeling of these new compounds was also presented in aim to study the mode of compounds orientation within CDC25 A and B. The reversibility of compounds 3, 4 and 5 was confirmed by application of MALDI-TOFMS technique.
\end{abstract}

Keywords: Chalcones, Coumarines, CDC25 phosphatase, MALDI-TOFMS, Molecular Modeling.

\section{Introduction}

CDC25 (Cell Division Cycle) is dual specificity phosphatase that play critical role in the division of eukaryotic cells. Up to date, three CDC25 isoforms were identified: A, B and C ${ }^{1-4}$. They dephosphorylate $\mathrm{CDK} /$ cyclin protein complexes which are key regulator of cell division. Noteworthy,CDC25B is needed for checkpoint recovery to repair DNA before mitosis ${ }^{3,5}$.

CDC25A and CDC25B are overexpressed in many different human cancers: (e.g.: breast cancer: $70 \%$ and 57\%, colorectal cancer: $47-53 \%$ esophageal cancer: $46-66 \%$ and $48-79 \%$ respectively) 1. Consequently, they appear as potential target in cancer therapy. Wide range of different scaffolds has been reported as CDC25 phosphatase inhibitors including quinoids, dysidiolide and large collection of miscellaneous structures ${ }^{6,7}$. Chalcones have numerous biological activities containing antihypertensive, antifungal, anticonvulsant, antiviral, antioxidant, anti-inflammatory, antimalarial, anti-HIV, antiprotozoal, antimicrobial,

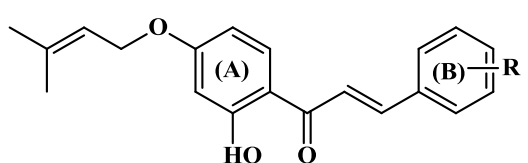

$\mathrm{I}: \mathrm{R}=\mathbf{4 - C l}$

II: $R=4$ -

III: $\mathrm{R}=3,4\left[\mathrm{CH}_{2} \mathrm{CH}=\mathrm{CCH}_{3}\right]$

inhibitor activity $(\mathrm{CDC} 25)>97,5 \%$ antifilarial, ${ }^{8,9}$ they also proved their antitumor activities through their action against many molecular targets ${ }^{10}$. The substituted chalcones in position 4 of ring (B) was even reported as CDC25 inhibitors with considerable activity (Figure 1) $)^{11}$.Coumarines are well known as anticancer ${ }^{12}$ active compounds with many different mechanisms like kinase inhibitors, apoptosis induction, angiogenetic inhibition, HSP90 inhibitors, telomerase inhibitor and antimitotic. ${ }^{13}$ Some coumarines have anticoagulant and cardiovascular properties (dicoumarol and warfarin) others have antibiotic activities as novobiocin and clorobiocin which are naturally occurring. ${ }^{14}$ Geiparvarin is another example of coumarine with dual activities: MAO-B inhibitory and antitumor. ${ }^{15}$ Coumarine has been combined with different pharmacophores, and showed antioxidant, anti-inflammatory, anticancer, and antimicrobial activities. 16 Some of them, hybridized with quinones ${ }^{17,18}$ or dimerized thanks to a disulfide bond of various lengths (Figure 1) ${ }^{19}$ are particularly active.

Figure 1. Examples of substituted and coumarines based chalcones inhibitors of CDC25s

*Corresponding author: Gilbert Kirsch

E-mail address: gilbert.kirsch@univ-lorraine.fr

DOI: http://dx.doi.org/10.13171/mjc.5.1/0160112/kirsch 
Synergistically, coumarine and chalcones combined structure appeared as promising anticancer molecules. They showed their abilities against number of human cancer cell lines, ${ }^{20}$ therefore, series of novel chalcones derived from coumarine were synthesized by aldol condensation. The obtained compounds were investigated by docking simulation and then evaluated in vitro on CDC25A and $\mathrm{B}$ enzymes.

\section{Results and Discussion}

\section{Chemistry}

All compounds were synthesized by well-known base-catalyzed aldol condensation ${ }^{21}$ between 3 acetyl coumarines and cinnamaldehyde. Previously, in our laboratory, substituted 3-acetyl coumarines were prepared starting from salicylaldehyde ${ }^{22}$ and ethylacetoacetate ${ }^{23,24}$. Commercially available cinnamaldehyde and other synthesized derivatives were introduced as condensed partner. In addition cinnamaldehydes compounds were synthesized with two different methods:

Method A consisted of the reduction of cinnamic acid using $\mathrm{LiAlH}(\mathrm{OtBu})_{4}{ }^{25}$ Method $\mathbf{B}$ was done by Wittig reaction ${ }^{26}$ between a benzaldehyde and an acetal ${ }^{27}$. All prepared compounds were purified by column chromatography (cyclohexane: ethyl acetate 9:1).

\section{Biological evaluation} Fluorimetric analysis

Compounds $\mathbf{1}$ to $\mathbf{8}$ were evaluated in-vitro against recombinant human CDC25 phosphatases by fluorimitric method. (Table 1)

Table 1. Inhibitory activity of product 1-8 with CDC25A and B (concentration of compounds $20 \mu \mathrm{M}$ )

\begin{tabular}{lll}
\hline compounds & \multicolumn{1}{c}{ CDC25A } & CDC25B \\
\hline DMSO & $0 \pm_{3.81}$ & $0 \pm_{1.25}$ \\
1 & $24.02 \pm_{3.98}$ & $30.42 \pm_{2.66}$ \\
2 & $16.59 \pm_{5.59}$ & $28.32 \pm_{3.95}$ \\
3 & $28.65 \pm_{3.23}$ & $18.39 \pm_{1.29}$ \\
4 & $35.95 \pm_{1.2}$ & $16.42 \pm_{1.13}$ \\
5 & $40.64 \pm_{0.92}$ & $54.94 \pm_{1.13}$ \\
6 & $32.72 \pm_{3.97}$ & $34.63 \pm_{2.31}$ \\
7 & $28.56 \pm_{2.38}$ & $32.89 \pm 1.09$ \\
8 & $7.34 \pm_{1.77}$ & $28.94 \pm_{3.43}$ \\
Naphtoquinone & $99.68 \pm_{4.52}$ & $99.41 \pm 3.12$ \\
\hline
\end{tabular}

The electrophilic substitution: $\mathrm{Cl}$ and $\mathrm{Br}$ on position 6 of the coumarine part led to inhibit CDC25A in higher extent than methoxy substituted analogue. The order of activity of these compounds was $4>3>2$. This order was inversed in the case of CDC25B. Introduction of methoxy group on the phenyl moiety increased the activity of compound 4 toward CDC25B but it diminished with CDC25A (from $35.95 \%$ to $7.34 \%$ ). Furthermore, comparing the activities of compounds 1,6 and 7; it showed that the methoxy group substitution on the phenyl ring increased the activity against both isoforms. The substitution on position 7 of coumarine with $\mathrm{N}, \mathrm{N}$-diethylamino group (compound 5) increased the inhibitory activity on CDC25A: $40.64 \pm 0.92 \%$ and CDC25B: $54.94 \pm 1.13 \%$ ). This compound was finally the most potent candidate among all tested structures (Table 1).

\section{MALDI-TOFMS}

Matrix-assisted laser desorption/ionizationtime-of-flight mass spectrometry (MALDI-TOFMS) was applied to check if the synthesized structures may be a candidate to CDC25 inhibition. In case of inhibition, the applied procedure is also able to inform about its reversibility or irreversibility. ${ }^{28}$

Compounds with the highest values in biological analysis as inhibitor $(\mathbf{3}, \mathbf{4}$ and $\mathbf{5})$ gave a positive results in MALDI-TOFMS Their protonated molecular ion directly appeared in the mass spectrum meaning that they behaves as reversible inhibitors as described by Sibille et al. ${ }^{29}$ and Bana et al. ${ }^{17}$. 

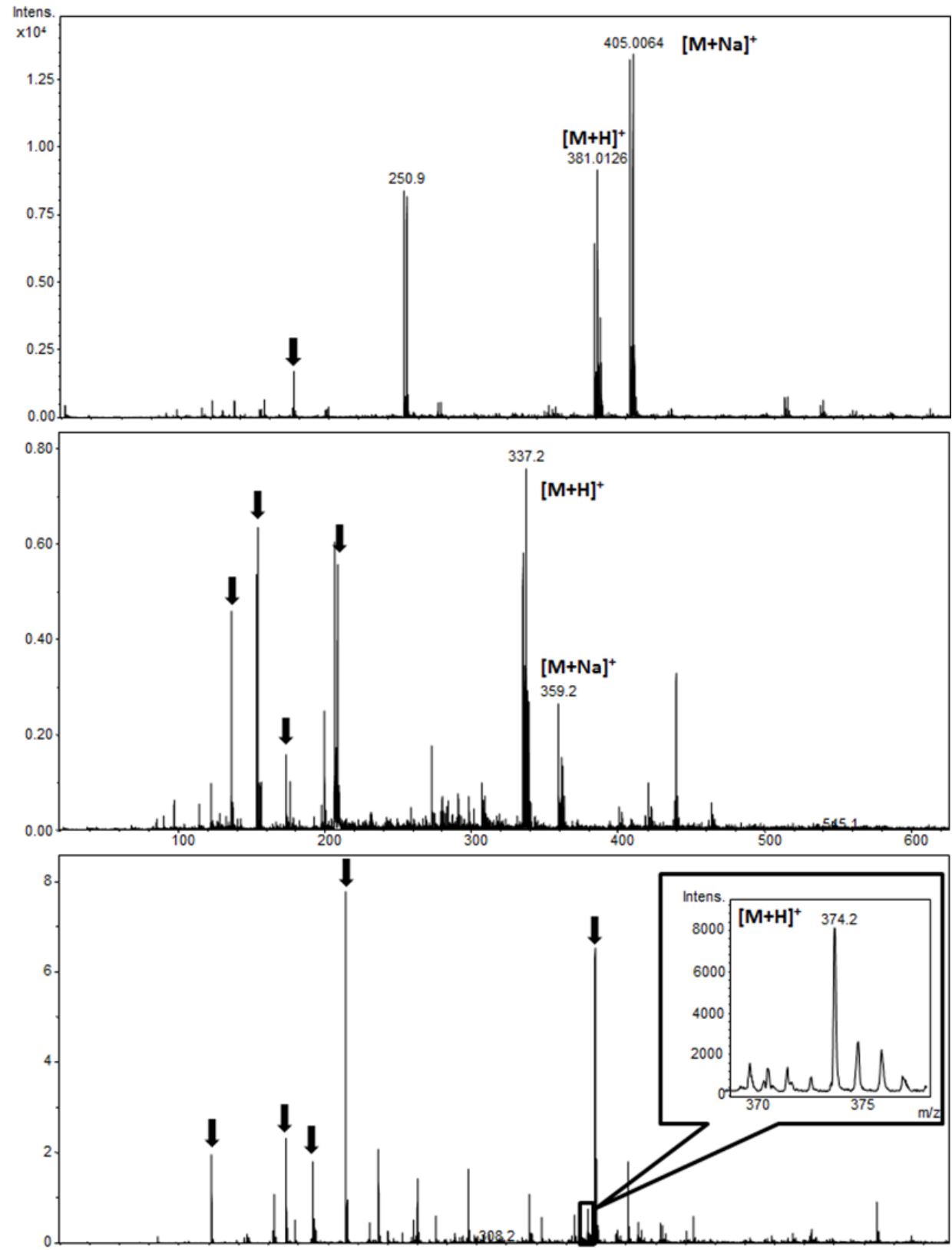

Figure 2. MALDI-TOF mass spectra (reflectron mode) of compounds $\mathbf{3}, \mathbf{4}$ and $\mathbf{5}$ from up chart to down (DHB matrix for compound 3 and HCCA matrix for compounds $\mathbf{4}$ and $\mathbf{5}, \mathrm{C}=2^{\mathrm{X}} 10^{-4} \mathrm{M}$ ) and CDC25A incubated with them. The ion $\mathrm{m} / \mathrm{z}=381.01, \mathrm{~m} / \mathrm{z}=337.2$ and $\mathrm{m} / \mathrm{z}=374.2$ corresponding to $\left[\mathrm{M}+\mathrm{H}^{+}\right]$of 3,4 and 5 respectively.

\section{Molecular modelling}

The molecular surface scanning of $\mathrm{CDC} 25 \mathrm{~B}$ reveals that its 3D structure exhibits a large groove just close to active cysteine ${ }^{30}$. Thus, this site called swimming pool also appears as an interesting target for inhibiting $\mathrm{CDC} 25$ by the binding of small molecules. ${ }^{31}$

Hence, the binding inside this catalytic site cannot only be taken into account as a dependable mode of inhibition. We suggested designing of chalcones derived from coumarine and investigating the designed products by docking simulation to test the mode of orientation of each moiety in relation to active and inhibitory sites. Possibility of formyl pyranone ring to surrogate the phosphate group of the native substrate was presumed ${ }^{6}$.
The surface structure of the CDC25B catalytic domain (1QB0) ${ }^{32}$, indicated that the distance between the shallow active site and the large groove is $7.3 \AA$. This distance must correspond to the linker length between the position 3 of the coumarine and the position 1 of the ring (B) of the chalcone-like moiety for inhibitor in 3D model.

Using CDC25B as key model, we found that conjugating ketone-diene chain $(n=2)$ provided a better linker length than a single double bond $(n=1)$ for our approach. Coumarine was one of the counterparts of choice while the other was substituted aromatic ring, and they were intended to be hybridized. 
Table 2. Synthesized derivatives and their molecular modeling interaction scores with CDC 25 phosphatase A and B indicating hydrogen bonds (number and length) and energy.

\begin{tabular}{|c|c|c|c|c|c|c|c|c|}
\hline \multirow{3}{*}{ Compounds } & \multirow[t]{3}{*}{$\mathrm{R} 1$} & \multirow[t]{3}{*}{$\mathrm{R} 2$} & \multirow{3}{*}{$\begin{array}{l}\text { CDC25A } \\
\text { Energy } \\
(\text { Kcal/mol) }\end{array}$} & & \multicolumn{3}{|l|}{ CDC25B } \\
\hline & & & & $\mathrm{HB}$ & & Energy & $\mathrm{HB}$ & \\
\hline & & & & $\mathrm{no}^{\circ}$ & $\begin{array}{l}\text { Length } \\
\left(\mathrm{A}^{\circ}\right)\end{array}$ & (Kcal/mol) & no ${ }^{\circ}$ & $\begin{array}{l}\text { Length } \\
\left(\mathrm{A}^{\circ}\right)\end{array}$ \\
\hline 1 & $\mathrm{H}$ & $\mathrm{H}$ & -4.5 & 3 & $2.4 ; 2.6$ & -6.9 & 1 & 2.8 \\
\hline 2 & 6-OMe & $\mathrm{H}$ & $-5,6$ & 1 & 2 & -7.3 & 1 & 2.6 \\
\hline 3 & $6-\mathrm{Br}$ & $\mathrm{H}$ & $-5,4$ & 2 & $2 ; 2.5$ & -6.5 & 1 & 2.7 \\
\hline 4 & $6-\mathrm{Cl}$ & $\mathrm{H}$ & $-5,6$ & 2 & $2.5 ; 2.6$ & -7.5 & 1 & 2.7 \\
\hline 5 & $7-\mathrm{N}\left(\mathrm{C}_{2} \mathrm{H}_{5}\right)_{2}$ & $\mathrm{H}$ & -3.9 & 2 & 2.7 & -7.7 & 2 & $2.5 ; 2.6$ \\
\hline 6 & $\mathrm{H}$ & 2,4-OMe & -6.2 & 1 & 2.9 & -7.6 & 2 & $2 ; 2.7$ \\
\hline 7 & $\mathrm{H}$ & 2,5-OMe & -6.1 & 2 & $2.6 ; 2.9$ & -7.8 & 2 & $2.3 ; 2.7$ \\
\hline 8 & $6-\mathrm{Cl}$ & 2,4-OMe & $-5,9$ & 2 & $2.7 ; 2.9$ & -7.4 & 1 & 2.2 \\
\hline
\end{tabular}

The docking study was achieved using AUTODOCK Vina ${ }^{33}$. We assumed that the coumarine compound is able to bind the cysteine of the catalytic site of CDC25B. Our docking study showed that, for the half of the structures tested, the coumarine part rather fitted inside the swimming pool of $\mathrm{CDC} 25 \mathrm{~B}$, while the chalcone part entered the active site. This is observed for compounds $\mathbf{1 , 4}, \mathbf{5}$ (Figure 3) and $\mathbf{6}$ blocked whereas it is the contrary for compounds $\mathbf{2 , 3}, \mathbf{7}$ and $\mathbf{8}$.

The docking with CDC25A was more challenging as the catalytic cysteine is located inside

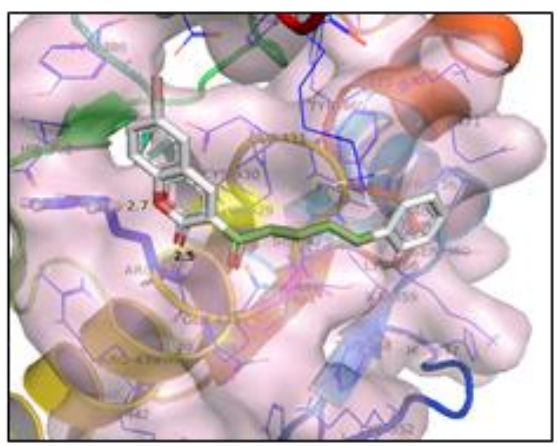

Figure 3. Compound 5 docking orientation with CDC25B interacting by two hydrogen bonds with Tyr428 and Arg544

Docking could not give the explanation of the inhibitory activity ${ }^{29,35-47}$, so it was necessary to synthesize these molecules and evaluated their biological activities with CDC25A and $\mathrm{B}$ then verification of their reversibility.

The CDC25s have two interesting sites: the active site and the swimming pool which can play an

important role, so it would be efficient if both of them are tested in same time. very shallow groove, with a very small cavity appearing unsuitable for fitting neither coumarine nor phenyl moiety of the compounds series. The docking results showed that the most of molecular poses are oriented in a way that the coumarine was toward the catalytic cysteine (cys430) which complying with phosphates group simulation assumption (1, 2, 3 (Figure 4), 4, 5, 6). (Table 1).

This orientations similar to phosphate cradling model of the native substrate ${ }^{34}$. Compounds $\mathbf{7}$ and $\mathbf{8}$ had their binding mode in the opposite direction.

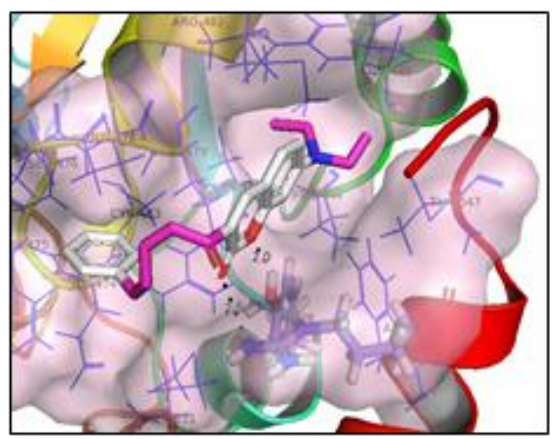

Figure 4. Docking of compound 3 with CDC25A forming two Hydrogen bonds with Arg436

It has been suggested that the hybrid structure may be more efficient at inhibiting CDC25s. Indeed, the first moiety of the inhibitor could fit the binding pocket (i.e. the swimming pool) while the other part could bind to the active cysteine ${ }^{48}$.

\section{Conclusion}

The antitumor characteristics of both coumarine and chalcones inspired our approach to design hybrid structures could block both grooves of the protein 
(active and inhibitory) highlighting the lack of toxicity in the same time.

Several chalcones derived from coumarine were synthesized, the binding modes of them were tested by molecular modelling simulation, the probability of phosphate surrogating by coumarine ring has been shown by certain derivatives. Biological evaluation revealed some activity of the compounds. $N, N$-diethylamino substitution on position 7 of coumarine (compound 5) increasing the inhibitory activity on both isoforms of CDC25. The derivatives proved to perform reversible inhibition by MALDITOF analysis (compounds $\mathbf{3}, \mathbf{4}$ and $\mathbf{5}$ ). The designed scaffold could be considered as a basis of further lead optimization in order to obtain better inhibition.

\section{Experimental Section}

\section{Chemistry}

All solvents were used as purchased unless otherwise noted.

Melting points were determined on a Buchi 530 digital melting point apparatus. ${ }^{1} \mathrm{H}$ and ${ }^{13} \mathrm{C}$ NMR spectra were recorded at $400 \mathrm{MHz}$ and $100 \mathrm{MHz}$, respectively, using $\mathrm{Me}_{4} \mathrm{Si}$ as the internal standard. Hydrogen coupling patterns are described as singlet (s), doublet (d), triplet (t), quartet (q), multiplet (m).

High resolution mass spectra were measured using a MicroTof-Q98 instrument in ESI mode. Column chromatography was performed using silica gel (60M, 0.04-0.063 mm). Thin layer chromatography (TLC) was performed using silica gel plates (POLYGRAM SIL G/UV ${ }_{254}, 0,20 \mathrm{~mm}$ ). For the visualization, TLC plates were placed under UV light.

\section{General procedure for synthesis of compounds 1 to 8}

In round bottom flask, 1.1 mmole of cinnamaldehydes and 1 mmole of substituted 3 -acetyl coumarine were mixed in ethanol, and stirred under reflux till dissolving of coumarine derivatives. Afterward, 5\% mole of piperidine was added and the reaction retained under reflux for $24 \mathrm{~h}$. When the reaction completed, the solution allowed to be cooled, and the product started to precipitate. The obtained solid was filtered and recrystallized using ethanol.

\section{3-(1-Oxo-5-phenyl-2Z，4Z-pentadien-1-yl)-2H-1- benzopyran-2-one (1) \\ Yellow powder; Yield: $52 \%$; Mp: $184^{\circ} \mathrm{C} .{ }^{49}$}

${ }^{1} \mathrm{H}$ NMR $\left(400 \mathrm{MHz}, \mathrm{CDCl}_{3}\right): \delta(\mathrm{ppm})=7.07(\mathrm{~d}, 1 \mathrm{H}$, $J=6 \mathrm{~Hz}) ; 7.08$ (d, 1H, J=8Hz); 7.35- $7.42(\mathrm{~m}, 5 \mathrm{H})$; $7.68-7.70(\mathrm{~d}, 1 \mathrm{H}, J=8 \mathrm{~Hz}) ; 7.67-7.69(\mathrm{dd}, 1 \mathrm{H}, J=8 \mathrm{~Hz}$, $J=1.6 \mathrm{~Hz}) ; 7.52-7.54(\mathrm{dd}, \quad 1 \mathrm{H}, \quad J=8.4 \mathrm{~Hz} ; \quad J=1.6$ $\mathrm{Hz}) ; 7.51-7.34(\mathrm{~d}, 1 \mathrm{H}, \quad J=9.6 \mathrm{~Hz}) ; \quad 7.49-7.52$ (d, $1 \mathrm{H}, J=10 \mathrm{~Hz}) ; 7.72(\mathrm{~d}, 1 \mathrm{H}, J=2.4 \mathrm{~Hz}) ; 8.60(\mathrm{~s}, 1 \mathrm{H})$; ${ }^{13} \mathrm{C}$ NMR $\left(100 \mathrm{MHz}, \mathrm{CDCl}_{3}\right): \delta(\mathrm{ppm})=116.7,118.6$, $124.9,125.39,127.3,127.4,128.9,129.3,130$, 134.1, 136.1, 142.7, 145.2, 147.8, 155.2, 186.3.
HRMS (ESI): $\mathrm{m} / \mathrm{z}[\mathrm{M}+\mathrm{Na}]^{+}$calculated for $\mathrm{C}_{20} \mathrm{H}_{14} \mathrm{O}_{2}$ : 302,32; found : 325,085

6-Methoxy- 3-(1-oxo-5-phenyl-2E,4E-pentadien-1yl)-2H-1-benzopyran-2-one (2)

Yellow powder; Yield: $24 \%$; $\mathrm{Mp}: 190^{\circ} \mathrm{C}$.

${ }^{1} \mathrm{H}$ NMR $\left(400 \mathrm{MHz}, \mathrm{CDCl}_{3}\right): \delta(\mathrm{ppm})=3.89(\mathrm{~s}, 3 \mathrm{H}$, $\left.\mathrm{OCH}_{3}\right) ; 7.07(\mathrm{~s}, 1 \mathrm{H}) ; 7.09(\mathrm{dd}, 2 \mathrm{H}, J=5.6 \mathrm{~Hz}$ and $J=2.5 \mathrm{~Hz}) ; 7.24(\mathrm{~d}, 1 \mathrm{H}, J=6 \mathrm{~Hz}) ; 7.32-7.35(\mathrm{~d}, 1 \mathrm{H}$, $J=14.4 \mathrm{~Hz}) ; 7.33-7.38(\mathrm{dd}, 1 \mathrm{H}, J=18 \mathrm{~Hz}) ; 7.36-7.40$ (d, 1H, J=14.4Hz) ;7.50 (d, 1H, J=6.8Hz); 7.53 (dd,2H, J=8Hz); $7.60(\mathrm{t}, 1 \mathrm{H}) ; 7.68(\mathrm{dd}, 1 \mathrm{H}, \mathrm{J}=18 \mathrm{~Hz})$; $8.50(\mathrm{~s}, 1 \mathrm{H}) ;{ }^{13} \mathrm{C}$ NMR $\left(100 \mathrm{MHz}, \mathrm{CDCl}_{3}\right)$ : $\delta(\mathrm{ppm})=55.9,111.0,117.8,118.9,122.6,125.5$, $127.3,127.4,127.5,128.9,129.3,136.1,142.7$, 145.1, 147.7, 149.9, 156.4, 159.4, 186.4.

HRMS (ESI): $\mathrm{m} / \mathrm{z}$ [ M+Na] ${ }^{+}$calculated for $\mathrm{C}_{21} \mathrm{H}_{16} \mathrm{O}_{4}$ : 332.35; found 355.095

6-Bromo-3-(1-oxo-5-phenyl-2E,4E-pentadien-1yl)-2H-1-benzopyran-2-one (3)

Yellow-orange powder; Yield: $54 \%$; Mp: $237^{\circ} \mathrm{C} .{ }^{50}$

${ }^{1} \mathrm{H}$ NMR $\left(400 \mathrm{MHz}, \mathrm{CDCl}_{3}\right): \delta(\mathrm{ppm})=7.08(\mathrm{~d}, 1 \mathrm{H}$, $J=6 \mathrm{~Hz}) ; 7.30(\mathrm{~d}, 1 \mathrm{H}, J=16 \mathrm{~Hz}) ; 7.38(\mathrm{~m}, 3 \mathrm{H}) ; 7.46$ $(\mathrm{d}, \mathrm{H}, J=16 \mathrm{~Hz}) ; 7.53(\mathrm{~d}, 2 \mathrm{H}, J=9.2 \mathrm{~Hz}) ; 7.68(\mathrm{dd}$, $1 \mathrm{H}, J=16.8 \mathrm{~Hz}) ; 7.71(\mathrm{dd}, 1 \mathrm{H}, J=16.8 \mathrm{~Hz}) ; 7.73(\mathrm{dd}$, $1 \mathrm{H}, J=2.4 \mathrm{~Hz}$ and $J=8 \mathrm{~Hz}) ; 7.81(\mathrm{~d}, 1 \mathrm{H}, J=2.4 \mathrm{~Hz})$; $8.48(\mathrm{~s}, 1 \mathrm{H}) ; 8.47(\mathrm{~s}, 1 \mathrm{H}) ;{ }^{13} \mathrm{C}$ NMR $(100 \mathrm{MHz}$, $\left.\mathrm{CDCl}_{3}\right): \delta(\mathrm{ppm})=117.5,118.4,119.7,125.5,127.5$, 128.9, 132.2, 137, 145.9, 154.1, 158.5, 194.9.

HRMS (ESI): $\mathrm{m} / \mathrm{z} \quad[\mathrm{M}+\mathrm{Na}]^{+}$calculated for $\mathrm{C}_{20} \mathrm{H}_{13} \mathrm{BrO}_{3}$ : 380,9; found: 402,994

6-Chloro-3-(1-oxo-5-phenyl-2E,4E-pentadien-1yl)-2H-1-benzopyran-2-one (4)

Yellow-orange powder; Yield: $70 \%$; Mp: $244^{\circ} \mathrm{C}^{50}$

${ }^{1} \mathrm{H}$ NMR $\left(400 \mathrm{MHz}, \mathrm{CDCl}_{3}\right): \delta(\mathrm{ppm})=7.08(\mathrm{~d}, 2 \mathrm{H}$, $J=6 \mathrm{~Hz}) ; 7.34(\mathrm{~d}, 1 \mathrm{H}, 14 \mathrm{~Hz}) ; 7.36(\mathrm{~d}, 1 \mathrm{H}$, $J=8.8 \mathrm{~Hz}) ; 7.41$ (m,2H); 7.46 (d, H, J=14.4Hz); 7.53 $(\mathrm{d}, 1 \mathrm{H}, \mathrm{J}=6.8 \mathrm{~Hz}) ; 7.61(\mathrm{dd}, 1 \mathrm{H}, \mathrm{J}=14 \mathrm{~Hz}) ; 7.55(\mathrm{~d}, 1 \mathrm{H}$, $\mathrm{J}=1.2 \mathrm{~Hz}) ; 7.7$ (dd, 1H, J=14Hz); $8.50 \quad(\mathrm{~s}, 1 \mathrm{H})$; $8.47(\mathrm{~s}, 1 \mathrm{H}) ; \quad{ }^{13} \mathrm{C} \quad \mathrm{NMR} \quad\left(100 \mathrm{MHz}, \mathrm{CDCl}_{3}\right)$ : $\delta(\mathrm{ppm})=118.1 ; 119.2 ; 125.5 ; 127.1 ; 127.2$; $127.5 ; 128.9 ; 129.1 ; 129.5 ; 130.3 ; 133.9 ; 134.2$; $143.1 ; 145.6 ; 146 ; 158.6 ; 195$.

HRMS (ESI): $\mathrm{m} / \mathrm{z} \quad[\mathrm{M}+\mathrm{Na}]^{+}$calculated for $\mathrm{C}_{20} \mathrm{H}_{13} \mathrm{ClO}_{3}$ : 336,06; found: 359,045

7-N,N-diethylamino-3-(1-oxo-5-phenyl-2Z,4Zpentadien-1-yl)-2H-1-benzopyran-2-one (5)

Orange powder; Yield: $33 \%$; Mp: $166^{\circ} \mathrm{C}^{51}$

${ }^{1} \mathrm{H}$ RMN $\left(400 \mathrm{MHz}, \mathrm{CDCl}_{3}\right): \delta(\mathrm{ppm})=1.17(\mathrm{t}, 6 \mathrm{H})$; $3.38(\mathrm{q}, 4 \mathrm{H}) ; 6.40(\mathrm{~d}, 1 \mathrm{H}, \mathrm{J}=1.6 \mathrm{~Hz}) ; 6.54(\mathrm{dd}, 1 \mathrm{H}$, $\mathrm{J}=2.5 \mathrm{~Hz}$ and $9.2 \mathrm{~Hz}) ; 6.98(\mathrm{~d}, 1 \mathrm{H}, J=10 \mathrm{~Hz}) ; 7.08$ $(\mathrm{dd}, 1 \mathrm{H}, J=10 \mathrm{~Hz}$ and $10.8 \mathrm{~Hz}) ; 7.23(\mathrm{~d}, 1 \mathrm{H}) ; 7.31$ $(\mathrm{m}, 5 \mathrm{H}) ; 7.33(\mathrm{~d}, \mathrm{H}, \mathrm{J}=9.2 \mathrm{~Hz}) ; 7.57(\mathrm{~d}, 1 \mathrm{H}, \quad J=$ $9.6 \mathrm{~Hz}) ; 7.60(\mathrm{dd}, 1 \mathrm{H}, J=9.6 \mathrm{~Hz}) ; 8.45(\mathrm{~s}: 1 \mathrm{H}) ;{ }^{13} \mathrm{C}$ RMN $\left(100 \mathrm{MHz}, \mathrm{CDCl}_{3}\right): \delta(\mathrm{ppm})=12.5 ; 30.6$; 96.7 ; 108.7 ; $109.8 ; 116.8 ; 127.3$; 127.8 ; 128.8 ; 
$131.8 ; 136.4 ; 141.2 ; 143.5 ; 148.6 ; 153.0 ; 158.6$; $160.9 ; 186.4$

HRMS (ESI): $\mathrm{m} / \mathrm{z} \quad[\mathrm{M}+\mathrm{Na}]^{+}$calculated for $\mathrm{C}_{24} \mathrm{H}_{23} \mathrm{NO}_{3}$ : 373,17; found: 396,158

\section{3-[1-Oxo-5-(2,4-diméthoxyphenyl)-2E,4E- pentadien-1-yl]-2H-1-benzopyran-2-one (6) Red Powder; Yield: $31 \%$; Mp: $195^{\circ} \mathrm{C}$}

${ }^{1} \mathrm{H}$ NMR $\left(400 \mathrm{MHz}, \mathrm{CDCl}_{3}\right): \delta(\mathrm{ppm})=3.88(\mathrm{~s}, 3 \mathrm{H})$; $3.92(\mathrm{~s}, 3 \mathrm{H}) ; 6.54-6.56(2 \mathrm{~d}, 2 \mathrm{H}, J=2.4 \mathrm{~Hz}$ and $J=8 \mathrm{~Hz})$, $6.48(\mathrm{~d}, 1 \mathrm{H}, J=2 \mathrm{~Hz}), 7.34-7.43(\mathrm{~m}, 3 \mathrm{H}), 7.63(\mathrm{~s}, 1 \mathrm{H})$, 7.66- 7.69 (dd,2H, J=18Hz), $7.89(\mathrm{~d}, 1 \mathrm{H}, J=16 \mathrm{~Hz})$, $8.17(\mathrm{~d}, 1 \mathrm{H}, J=16 \mathrm{~Hz}), 8.56(\mathrm{~s}, 1 \mathrm{H}) ;{ }^{13} \mathrm{C}$ NMR $(100$ $\left.\mathrm{MHz}, \mathrm{CDCl}_{3}\right): \delta(\mathrm{ppm})=55.5,98.4,105.6,116.6$, $117.2,118.7,122,124.8,126.1,129.8,131.1,133.8$, 140.7, 147.3, 155.1, 159.3, 160.7, 163.5, 186.8. HRMS (ESI): $\mathrm{m} / \mathrm{z}$ [ M+Na] ${ }^{+}$calculated for $\mathrm{C}_{22} \mathrm{H}_{18} \mathrm{O}_{5}$ : 362.12 ; found 385.015

\section{3-[1-Oxo-5-(2,5-diméthoxyphenyl)-2E,4E- pentadien-1-yl]-2H-1-benzopyran-2-one (7) Yellow powder; Yield: $36 \%$; Mp: $132^{\circ} \mathrm{C}$.}

${ }^{1} \mathrm{H}$ RMN $\left(400 \mathrm{MHz}, \mathrm{CDCl}_{3}\right): \delta(\mathrm{ppm})=3.75(\mathrm{~s}, 3 \mathrm{H}$, $\mathrm{OMe}), 3.81(\mathrm{~s}, 3 \mathrm{H}, \mathrm{OMe}), 6.48(\mathrm{~d}, 1 \mathrm{H}, \quad J=8 \mathrm{~Hz})$; $6.79(\mathrm{~d}, 1 \mathrm{H}, \quad J=8.8 \mathrm{~Hz}) ; \quad 6.88 \quad\left(\mathrm{dd}, 1 \mathrm{H}, \quad J_{l}=6 \mathrm{~Hz}\right.$, $\left.J_{2}=2.4 \mathrm{~Hz}\right), 7.14 \quad(\mathrm{~d}, 1 \mathrm{H}, \quad J=3.2 \mathrm{~Hz}), 7.36 \quad(\mathrm{dd}, 1 \mathrm{H}$, $J=14.4 \mathrm{~Hz}) ; 7.38(\mathrm{dd}, 1 \mathrm{H}, J=14.4 \mathrm{~Hz}) ; 7.58 \quad(\mathrm{~m}, 2 \mathrm{H})$; $7.86(\mathrm{~d}, 1 \mathrm{H}, \quad J=16 \mathrm{~Hz}), \quad 8.10 \quad(\mathrm{~d}, \quad 1 \mathrm{H}, \quad J=16 \mathrm{~Hz})$; $8.17(\mathrm{~d}, 1 \mathrm{H}, \mathrm{J}=7.2 \mathrm{~Hz}) ; 8.48 \quad(\mathrm{~s}, 1 \mathrm{H}) .{ }^{13} \mathrm{C}$ RMN $(100$ $\left.\mathrm{MHz}, \mathrm{CDCl}_{3}\right): \delta(\mathrm{ppm})=55.9,56.2,112.6,113.4$, $116.7,118.2,118.6,124.4,124.6,124.9,125.7$, $129.9,134.0,140,147.7,153.6,153.7,155.2,159.3$. HRMS (ESI): $\mathrm{m} / \mathrm{z}$ [ M+Na] ${ }^{+}$calculated for $\mathrm{C}_{22} \mathrm{H}_{18} \mathrm{O}_{5}$ : 362.12; found 385.015

\section{6-Chloro-3-[1-oxo-5-(2,4-diméthoxyphenyl)-} 2E,4E-pentadien-1-yl]-2H-1-benzopyran-2-one (8) Colorless solid, Yield: $20 \%$; Mp: $80^{\circ} \mathrm{C}$

${ }^{1} \mathrm{H} \mathrm{RMN}\left(400 \mathrm{MHz}, \mathrm{CDCl}_{3}\right): \delta(\mathrm{ppm})=3.77(\mathrm{~s}, 3 \mathrm{H})$; $3.88(\mathrm{~s}, 3 \mathrm{H}), \quad 6.34(\mathrm{~s} 1 \mathrm{H}) ; \quad 6.38(\mathrm{dd}, 2 \mathrm{H}, \quad J=8 \mathrm{~Hz})$; 6.4(dd,1H, J=16Hz); $6.7(\mathrm{~d}, 1 \mathrm{H}, \mathrm{J}=15.5 \mathrm{~Hz})$; $7.36(\mathrm{~d}, 1 \mathrm{H}, J=16 \mathrm{~Hz}) ; 7.43(\mathrm{dd}, 2 \mathrm{H}, \mathrm{J}=8.4 \mathrm{~Hz}) ; 7.57$ $(\mathrm{dd}, 1 \mathrm{H}, J=15.5 \mathrm{~Hz}) ; 7.24(\mathrm{~d}, \mathrm{H}) ; 7.99(\mathrm{~s}, 1 \mathrm{H}) ; 8.47$ $(\mathrm{s}, 1 \mathrm{H}) ; \quad{ }^{13} \mathrm{C} \quad \mathrm{RMN} \quad\left(100 \mathrm{MHz}, \mathrm{CDCl}_{3}\right)$ : $\delta(\mathrm{ppm})=55.4,60.1,98.5,105.2,116.2,116.7,130.4$, 139.9, 145, 153, 159.8, 162.6, 167.9, 182.49, 199.13. HRMS (ESI): $\mathrm{m} / \mathrm{z}[\mathrm{M}+\mathrm{Na}]^{+}$calculated for $\mathrm{C}_{22} \mathrm{H}_{17}$ $\mathrm{ClO}_{5}$ : 396.08; found 418.9755

\section{Docking simulation}

$3 \mathrm{D}$ structures of all compounds were designed and the best conformer picked by VEGA ZZ 2.3.1 software ${ }^{52}$. It was also used for adjusting the force field of the molecule as AMBER, and atomic charge which applied as Gasteiger, products was energetically minimized using MOPAC and finally introduced as PDB format.

CDC25B (1QB0) and CDC25A (1C25) ${ }^{53}$ phosphatase catalytic domain was obtained from the Protein Data Bank. AutoDock Tools was employed to remove unwanted elements and water. It transformed to PDBQT file format, to make them ready for docking which was processed using AUTODOCK Vina. Docking parameters was adjusted as the following

CDC25B: Grid box centered in $\mathrm{X}=18.3, \mathrm{Y}=4.6$, $\mathrm{Z}=16.3$, Volume $=23 * 23 * 23 \AA$

CDC25A: Grid box center: $X=11.6, Y=40.2$, $\mathrm{Z}=69.3$, Volume $=16^{*} 16^{*} 18 \AA$

Pymol software ${ }^{54}$ was used for visualization and determination of the interaction of compounds with enzyme.

\section{Biological evaluation}

Recombinant human CDC25 phosphatases were prepared by previously described method ${ }^{19}$. Assay took place in 96-well plates; buffer solution was adjusted in the following quantities: $50 \mathrm{mM}$ Tris$\mathrm{HCl}, 50 \mathrm{mM} \mathrm{NaCl}, 1 \mathrm{mM}$ EDTA, and $0.1 \%$ Bovine Serum Albumine, $\mathrm{pH}$ 8.1. Incubation period of substrate 3-O-methylfluorescein phosphate with enzyme was $2 \mathrm{~h}$ in $30^{\circ} \mathrm{C}$. Enzyme was exposed to the inhibitors for $20 \mathrm{~min}$ and the residual activity of the enzyme has been determined by fluorimetric method.

\section{MALDI/TOFMS}

All compounds were dissolved in ethanol at a concentration of $10^{-2} \mathrm{M}$. The solution were then further diluted to $2 \cdot 10^{-3} \mathrm{M}$ with ultrapure water. Phosphatases CDC25A was solubilized in Tris A buffer $(50 \mathrm{mM}$ Tris, $50 \mathrm{mM} \mathrm{NaCl}, 1 \mathrm{mM}$ EDTA and $1 \mathrm{mM}$ dithiothreitol [DTT], $\mathrm{pH}$ 8.0) at a concentration of $8.10^{-5} \mathrm{M}$. One hundred and fifty $\mu \mathrm{l}$ of CDC25A was incubated with $40 \mu \mathrm{l}$ of compounds for $1 \mathrm{~h}$. Solution was ultracentrifugated on Microcon filter unit with a mass cutoff of $30 \mathrm{kDa}$ (Millipore). The unbound material was eliminated by centrifugation during $10 \mathrm{~min}$ at $12,000 \mathrm{rpm}$ and washed three times by $100 \mu \mathrm{L}$ of ultrapure water. The retentate was then dissolved in $20 \mu \mathrm{L}$ of ultrapure water. Two $\mu 1$ of the retentate was spotted on the MALDI plate ( 2 spot for sample in two line), evaporated to dryness at room temperature. Then one $\mu l$ of saturated solution of DHB (dihydroxybenzoic acid) was deposited for one of spot and HCCA $(\alpha-$ hydroxycyanocinnamic acid) was deposited for the second spot of each sample on the plate to evaluate the response of each compound with both of matrix, and conserved the spectrum which had the intense response.

The presence of the protonated molecular ion in the MS spectrum is corresponding to a reversible inhibitor activity.

\section{References}

1. R Boutros, V Lobjois, B Ducommun; CDC25 phosphatases in cancer cells: key players? Good targets? ; Nat Rev Cancer; 2007;7(7);495-507.

2. B Baratte, L Meijer, K Galaktionov, D Beach; Screening for antimitotic compounds using the cdc25 tyrosine phosphatase, an activator of the 
mitosis-inducing p34cdc2/cyclin Bcdc13 protein kinase; Anticancer Res; 1992;12(3);873-880.

3. SW Ham, BI Carr; Cell Division Cycle 25 (Cdc25) Phosphatase Inhibitors as Antitumor Agents; Drug Des Rev - Online; 2004;1(2);10.

4. P Kaldis; The cdk-activating kinase (CAK): from yeast to mammals; Cell Mol Life Sci C. 1999;55(2);284-296.

5. B Bugler et al. Genotoxic-activated G2-M checkpoint exit is dependent on CDC25B phosphatase expression; Mol Cancer Ther; 2006;5(6);1446-1451.

6. MO Contour-Galcera, A Sidhu, G Prévost, D Bigg, B Ducommun; What's new on CDC25 phosphatase inhibitors; Pharmacol Ther; 2007;115(1);1-12.

7. A Lavecchia., C Di Giovanni, E Novellino; CDC25 Phosphatase Inhibitors: An Update. Mini Rev Med Chem; 2012;12(1);62-73.

8. BP Bandgar, SA Patil, BL Korbad, SH Nile, CN Khobragade; Synthesis and biological evaluation of beta-chloro vinyl chalcones as inhibitors of TNF-alpha and IL-6 with antimicrobial activity; Eur J Med Chem; 2010;45(6);2629-2633.

9. Singh P, Anand A, Kumar V; Recent developments in biological activities of chalcones: A mini review; Eur J Med Chem; 2014;85C;758-777.

10. DK Mahapatra, SK Bharti, V Asati; Anticancer chalcones: Structural and molecular target perspectives; Eur J Med Chem; 2015;98; 69-114.

11. J Zhang, F-J Ji, Y Gu, X-Y Zhang, S-X Qiao; Chalcones derivatives as potent Cell division cycle 25B phosphatase inhibitors; Pharmacol Rep; 2014;66(3);515-519.

12. ME Riveiro, et al; Coumarins: old compounds with novel promising therapeutic perspectives; Curr Med Chem; 2010;17;1325-1338.

13. A Thakur, R Singla, V Jaitak; Coumarins as anticancer agents: A review on synthetic strategies, mechanism of action and SAR studies; Eur J Med Chem; 2015;101;476-495.

14. F Borges, F Roleira, N Milhazes, L Santana, E Uriarte; Simple Coumarins and Analogues in Medicinal Chemistry: Occurrence, Synthesis and Biological Activity; Curr Med Chem.;2005; 12(8);887-916.

15. A Carotti, et al; Natural and synthetic geiparvarins are strong and selective MAO-B inhibitors. Synthesis and SAR studies; Bioorganic Med Chem Lett; 2002;12(24); 3551-3555.

16. S Sandhu, Y Bansal, O Silakari, G Bansal; Coumarin hybrids as novel therapeutic agents; Bioorg Med Chem; 2014;22(15);3806-3814.

17. E Bana, et al.; A novel coumarin-quinone derivative SV37 inhibits CDC25 phosphatases, impairs proliferation, and induces cell death; Mol Carcinog; 2015;54(3); 229-241.
18. S Valente, et al.; Reactivity of 4-Vinyl-2 H -1benzopyran-2-ones in Diels-Alder Cycloaddition Reactions: Access to CoumarinBased Polycycles with Cdc25 PhosphataseInhibiting Activity; European J Org Chem;2013(14):2869-2877.

19. S Valente, E Bana, E Viry, D Bagrel, G Kirsch; Synthesis and biological evaluation of novel coumarin-based inhibitors of Cdc25 phosphatases; Bioorg Med Chem Lett. 2010;20(19):5827-5830.

20. KV Sashidhara, A Kumar, M. Kumar, J. Sarkar, Sinha S; Synthesis and in vitro evaluation of novel coumarin-chalcone hybrids as potential anticancer agents; Bioorg Med Chem Lett; 2010;20(24);7205-7211.

21. A Wurtz.; Ueber einen Aldehyd-Alkohol; $J$ für Prakt Chemie; 1872;5(1);457-464.

22. T Hirai, H Togo; Preparation and Synthetic Use of Polymer-Supported Acetoacetate Reagent; Synthesis (Stuttg); 2005;(16);2664-2668.

23. S S Starčević, et al; Synthesis and biological evaluation of (6- and 7-Phenyl) coumarin derivatives as selective nonsteroidal inhibitors of $17 \beta$-hydroxysteroid dehydrogenase type 1 ; J Med Chem; 2011;54(1);248-261.

24. Ra Finnegan, B Gilbert, Ej Eisenbraun, C Djerassi; Naturally Occurring Oxygen Heterocyclics. VIII. 1 Synthesis of Some Coumarins Related to Mammein 2; J Org Chem; 1960;25(12);2169-2173.

25. A I Vedernikov, S P Gromov; Convenient Method for the Preparation of Crown Ether Cinnamaldehydes; Synthesis (Stuttg);2001(06);0889-0892.

26. G Wittig, U Schollkopf; Über Triphenylphosphinmethylene als olefinbildende Reagenzien (I. Mitteil.); Chem Ber.;1954;87(9);1318-1330.

27. A a Wube, et al.; Design, synthesis and antimycobacterial activities of 1-methyl-2alkenyl-4(1H)-quinolones; Bioorg Med Chem; 2011;19(1);567-579.

28. E Sibille, et al. Development of a matrixassisted laser desorption / ionization - mass spectrometry screening test to evidence reversible and irreversible inhibitors of CDC25 phosphatases; Anal Biochem; 2012;430(1); 83-91.

29. H Park, et al.; Discovery of Novel and Potent Cdc25 Phosphatase Inhibitors Based on the Structure-Based De Novo Design; Bull Korean Chem Soc; 2009;30(6);1313-1316.

30. J Rudolph.; Cdc25 phosphatases: structure, specificity, and mechanism; Biochemistry. 2007;46(12);3595-3604.

31. J Rudolph.; Targeting the Neighbor's Pool; Mol Pharmacol; 2004;66(4):780-782.

32. PDB code:1QB0, http://www.rcsb.org/pdb/Welcome.do.

33. O Trott, AJ Olson; AutoDock Vina; J Comput Chem; 2010;31;445-461. 
34. J Sohn, et al. Experimental validation of the docking orientation of $\mathrm{Cdc} 25$ with its $\mathrm{Cdk} 2$ CycA protein substrate; Biochemistry; 2005;44(50);16563-16573.

35. J Markovits, et al; Differential effects of two growth inhibitory $\mathrm{K}$ vitamin analogs on cell cycle regulating proteins in human hepatoma cells; Life Sci; 2003;72(24);2769-2784.

36. E Braud, et al.; Novel naphthoquinone and quinolinedione inhibitors of CDC25 phosphatase activity with antiproliferative properties; Bioorg Med Chem; 2008;16(19);9040-9049.

37. M Sarkis, et al.; Design and synthesis of novel bis-thiazolone derivatives as micromolar CDC25 phosphatase inhibitors: Effect of dimerisation on phosphatase inhibition; Bioorganic Med Chem Lett; 2012;22(24); 7345-7350.

38. S Kar, M Wang, SW Ham, BI Carr; H32, a non-quinone sulfone analog of vitamin $\mathrm{K} 3$, inhibits human hepatoma cell growth by inhibiting Cdc25 and activating ERK; Cancer Biol Ther; 2006;5(10);1340-1347.

39. JW Yang, et al.; A unique and rapid approach toward the efficient development of novel protein tyrosine phosphatase (PTP) inhibitors based on "clicked" pseudo-glycopeptides; Bioorganic Med Chem Lett; 2011;21(4); 1092-1096.

40. XP He, et al.; Facile fabrication of promising protein tyrosine phosphatase (PTP) inhibitor entities based on "clicked" serine/threoninemonosaccharide hybrids; Bioorganic Med Chem; 2011;19(13);3892-3900.

41. XP He, et al.; Discovering the distinct inhibitory effects between C4-epimeric glycosyl amino acids: new insight into the development of protein tyrosine phosphatase inhibitors; Glycoconj J; 2011;28(7);493-497.

42. S Kolb, et al.; Development of novel thiazolopyrimidines as CDC25B phosphatase inhibitors; ChemMedChem; 2009;4(4);633-648.

43. A Lavecchia, S Cosconati, V Limongelli, E Novellino; Modeling of Cdc25B dual specifity protein phosphatase inhibitors: Docking of ligands and enzymatic inhibition mechanism; ChemMedChem; 2006;1(5);540550 .
44. H Park, YH Jeon; Toward the virtual screening of Cdc25A phosphatase inhibitors with the homology modeled protein structure; $\mathrm{J} \mathrm{Mol}$ Model; 2008; 14(9);833-841.

45. M Montes, et al.; Receptor-based virtual ligand screening for the identification of novel CDC25 phosphatase inhibitors; J Chem Inf Model; 2008;48(1);157-165.

46. H Park, et al; : Discovery of novel Cdc25 phosphatase inhibitors with micromolar activity based on the structure-based virtual screening; J Med Chem; 2008;51(18);5533-5541.

47. JC Collins, et al.; Prospective use of molecular field points in ligand-based virtual screening: efficient identification of new reversible $\mathrm{Cdc} 25$ inhibitors; Medchemcomm. 2013;4;1148.

48. T Besset, et al.; Preparation and evaluation of a set of bis(methoxycarbonylmethylthio) heteroquinones as $\mathrm{CDC} 25 \mathrm{~B}$ phosphatase inhibitors; Eur J Chem; 2011;2(4);433-440.

49. OO Ajani, OC Nwinyi; Microwave-assisted synthesis and evaluation of antimicrobial activity of 3-\{3-(s-aryl and s-heteroaromatic)acryloyl $\}-2 \mathrm{H}$-chromen-2one derivatives; J Heterocycl Chem; 2010;47(1);179-187.

50. BS Jayashree, S Arora, KN Venugopala; Microwave Assisted Synthesis of Substituted Coumarinyl Chalcones as Reaction Intermediates for Biologically Important Coumarinyl Heterocycles; Asian J Chem; 2008;20(1);1-7.

51. DP Specht, SY Farid, KL Payne, CG Houle; Co-initiator compositions for photopolymerization containing 3-ketosubstituted coumarins, photopolymerizable composition and photographic element; Europeen Patent EP 22188 A2 ; 1981;Eur. Pat. Appl.; 1981; Jan 14, 1981

52. A Pedretti, L Villa, G Vistoli; VEGA - An open platform to develop chemo-bio-informatics applications, using plug-in architecture and script programming; J Comput Aided Mol Des; 2004;18(3);167-173.

53. PDB code:1C25, http://www.rcsb.org/pdb/Welcome.do.

54. WL DeLano; The PyMOL Molecular Graphics System; Schrödinger LLC wwwpymolorg; 2002; Version 1.:http://www.pymol.org. 